\title{
The fimbriae of human enterotoxigenic Escherichia coli strain 334 are related to CS5 fimbriae
}

\author{
Martin L. Hibberd,${ }^{1} \uparrow$ Moyra M. McConnell, ${ }^{1 *}$ AnNe M. Field ${ }^{2}$ and Bernard Rowe ${ }^{1}$ \\ ${ }^{1}$ Division of Enteric Pathogens and ${ }^{2}$ Virus Reference Laboratory, Central Public Health Laboratory, \\ 61 Colindale Avenue, London NW9 5HT, UK
}

(Received 23 April 1990; revised 26 July 1990; accepted 24 August 1990)

\begin{abstract}
Escherichia coli strain 334 is a human enterotoxigenic strain of serotype 015:H11 which had previously been shown to produce 'attachment pili'. These fimbriae were compared with other colonization factors. From strain 334 a mannose-resistant haemagglutination positive colony $334 \mathrm{~A}$ and a mannose-resistant haemagglutination negative variant 334C were isolated. By electron microscopy the fimbriae of strain 334A were shown to have a helical structure resembling coli-surface-associated antigen (CS5) fimbriae. An antiserum was raised to strain 334A and absorbed with a fimbriae-negative variant of that strain, 334C. By immuno-electron microscopy this antiserum was shown to coat fimbriae of strain 334A but not CS5 fimbriae produced by strain E17018A. Conversely, CS5 antiserum did not coat the fimbriae produced by strain 334A. No antigenic cross-reaction was detected between these intact fimbriae when anti-strain 334A serum and CS5 antiserum were used in immunodiffusion tests. By enzyme-linked immunosorbent assays (ELISAs) the fimbriae of strain 334A were shown to be antigenically unrelated to most other human ETEC adhesins, namely colonization factor antigens (CFA/I, CFA/III and CFA/IV), coli-surface-associated antigens (CS1, CS2, CS3, CS4, CS6 and CS17) and putative colonization factors (PCFO159:H4 and PCFO166). However, a heated suspension of strain 334A reacted weakly with CS5 antiserum in an ELISA. By SDS-PAGE the fimbriae of strain 334A were shown to consist of subunits of similar size to CS5 subunits, that is about $21.5 \mathrm{kDa}$. Western immunoblotting revealed that the subunits of 334A and CS5 fimbriae shared common epitopes. Expression of 334A fimbriae was controlled by a plasmid which also coded for enterotoxin production, a system similar to that reported for a number of other human ETEC attachment factors. Strain 334A fimbriae have therefore been designated as CS7 fimbriae. Surveillance with CS7 anti-serum of ETEC with no known attachment factors showed two other strains of serotype O15:H11, one strain of serotype O103:H49 and 20 strains of serotypes O114:H49 and $\mathrm{H}^{-}$to possess CS7 fimbriae.
\end{abstract}

\section{Introduction}

Enterotoxigenic Escherichia coli (ETEC) are an important cause of infantile diarrhoea in developing countries and visitors to these areas may also suffer from ETEC associated diarrhoea (Sack, 1975; Merson et al., 1980). ETEC cause disease by attaching to the small intestine epithelial cells and releasing enterotoxins, either heat labile (LT), heat stable (ST) or both. Attachment leads to colonization and is mediated by colonization factors

† Present address: King's College School of Medicine and Dentistry, Bessemer Road, London SE5 9PJ, UK.

Abbreviations: CFA, colonization factor antigen; CS, coli-surfaceassociated antigen; ETEC, enterotoxigenic Escherichia coli, LT, heatlabile enterotoxin; MRHA, mannose-resistant haemagglutination; MSHA, mannose-sensitive haemagglutination; PCF, putative colonization factor; ST, heat-stable enterotoxin. which are usually fimbriae (Parry \& Rooke, 1985). Immunologically, a number of colonization factor antigens (CFAs) have been recognized. CFA/I and CFA/II were originally identified by Evans et al. (1975, 1978). CFA/I is a single fimbrial antigen found in $\mathrm{ST}^{+}$ and $\mathrm{ST}^{+} \mathrm{LT}^{+}$producing ETEC of at least 15 serogroups (McConnell et al., 1989a) whereas CFA/II is known to be a complex consisting of three coli-surface-associated (CS) antigens (Cravioto et al., 1982; Smyth, 1982) a fibrillar antigen CS3 which is present as a single antigen on $\mathrm{ST}^{+} \mathrm{LT}^{+}$strains of eight serogroups (McConnell et al., 1989a) and with either of two other fimbrial antigens, CS1 or CS2 on $\mathrm{ST}^{+} \mathrm{LT}^{+}$strains of serotype O6:H16 (Smyth, 1982). CFA/IV, originally found on strain E8775, was also shown to be an antigen complex, consisting of CS6 which appears to be non-fimbrial with either CS4 or CS5 fimbriae (Thomas et al., 1985). 
$\mathrm{ST}^{+} \mathrm{LT}^{+}$or $\mathrm{ST}^{+}$strains of serotype $\mathrm{O} 25: \mathrm{H} 42$ have been shown to produce CS4 together with CS6, while $\mathrm{ST}^{+}$ strains of six serogroups produce CS5 and CS6 (Thomas et al., 1985; McConnell et al., 1989a). $\mathrm{ST}^{+}$strains of six serogroups of ETEC which produce CS6 without CS4 or CS5 have also been identified (McConnell et al., 1986).

Other possible human colonization factors have been described, viz. CFA/III found with CS6 on $\mathrm{LT}^{+}$strains of serotypes $\mathrm{O} 25: \mathrm{H} 16$ and $\mathrm{O} 25: \mathrm{H}^{-}$(Honda et al., 1984; McConnell \& Rowe, 1989), putative colonization factor (PCF) $0159: \mathrm{H} 4$ on $\mathrm{ST}^{+} \mathrm{LT}^{+}$strains of serotypes O159:H4 or H20 (Tacket et al., 1987; McConnell \& Rowe, 1989), CFA/VI, on a $\mathrm{LT}^{+}$strain of serotype O9: $\mathrm{H}^{-}$(Heuzenroeder et al., 1990), PCFO166 on $\mathrm{ST}^{+}$ and $\mathrm{ST}^{+} \mathrm{LT}^{+} E$. coli of three serogroups (McConnell et al., 1989a) and CS17 on $\mathrm{LT}^{+}$strains of five serogroups (McConnell et al., 1990). Other less well investigated factors include INT 407 on ETEC of serotype $\mathrm{O} 27: \mathrm{H} 7$ or O27:H20 (Thomas, 1985) the fimbriae on ETEC of serotype O148:H28 (Knutton et al., 1987), the nonfimbrial adhesin 2230 on a $\mathrm{ST}^{+}$strain of serotype O25:H16 (Darfeuille-Michaud et al., 1986) and the fimbriae on ETEC strains 334 (serotype O15:H11), M9800-5 (O6:H16) and D542 (O78:H11), originally termed 'attachment pili' because they could bind to erythrocytes and human buccal cells (Thorne et al., 1979; Deneke et al., 1981; Thomas, 1985).

The attachment pili of strains 334, M9800-5 and D542 were classified as belonging to three different antigenic types but their relationship to CFA/I and CFA/II was not clear (Deneke et al., 1981). Strains 334, M9800-5 and D542 were sent to the Division of Enteric Pathogens by C. F. Deneke where they were compared with strains producing CFA/I, CFA/II and CFA/IV by immunodiffusion (Thomas, 1985). Strain D542 was found to express CFA/I fimbriae and strain M9800-5 to express CS2 and CS3 fimbriae. In immunodiffusion tests the fimbriae of strain 334 did not show any similarity to the adhesins CFA/I, and CS1 to CS6. Using enzyme-linked immunosorbent assays (ELISAs) we have now tested strain 334 with absorbed antisera raised against strains producing CFA/I and CS1 to CS6 and the more recently identified PCFs and compared the properties of the fimbriae of strain 334 with those of known adhesins. In addition, we have tested strains from a large panel of ETEC for fimbriae antigenically similar to those expressed by strain 334.

\section{Methods}

Bacterial strains. ETEC strain 334 was received from C. F. Deneke (Thorne et al., 1979; Deneke et al., 1981). The other ETEC strains used in this study were from the culture collection in the Division of Enteric Pathogens where they were serotyped and tested for toxin production.
One-hundred and forty-one ETEC with known colonization factors were screened for strain 334 type fimbriae. These consisted of : 21 $\mathrm{CFA} / \mathrm{I}^{+} \mathrm{ST}^{+}$or $\mathrm{ST}^{+} \mathrm{LT}^{+}$strains of serogroups $\mathrm{O} 4, \mathrm{O} 63, \mathrm{O} 78, \mathrm{O} 126$, $\mathrm{O} 128,0136$ and $\mathrm{O} 153$, three $\mathrm{CS} 1^{+} \mathrm{CS}_{3}{ }^{+} \mathrm{ST}^{+} \mathrm{LT}^{+}$strains of serogroups $\mathrm{O} 6$ and $\mathrm{O} 139$, two $\mathrm{CS} 2{ }^{+} \mathrm{CS}_{3}{ }^{+} \mathrm{ST}^{+} \mathrm{LT}^{+}$strains of serogroup $\mathrm{O} 6$, eight $\mathrm{CS}^{+} \mathrm{ST}^{+} \mathrm{LT}^{+}$strains of serogroups $\mathrm{O} 8, \mathrm{O} 85, \mathrm{O} 115$ and $\mathrm{O} 139$, five $\mathrm{CFA} / \mathrm{III}^{+} \mathrm{CS}^{+} \mathrm{LT}^{+}$strains of serogroup $\mathrm{O} 25$, four $\mathrm{CS}^{+} \mathrm{CS}^{+} \mathrm{ST}^{+}$or $\mathrm{ST}^{+} \mathrm{LT}^{+}$strains of serogroup $\mathrm{O} 25,15 \mathrm{CS}^{+} \mathrm{CS}^{+} \mathrm{ST}^{+}$strains of serogroups $\mathrm{O} 29, \mathrm{O} 114, \mathrm{O} 115$ and $\mathrm{O} 167$ and $24 \mathrm{CS}^{+} \mathrm{LT}^{+}$strains of serogroups $\mathrm{O} 27, \mathrm{O} 79, \mathrm{O} 89, \mathrm{O} 148, \mathrm{O} 153, \mathrm{O} 159$ and $\mathrm{O} 169$, four PCFO159: $\mathrm{H}^{+}{ }^{+} \mathrm{ST}^{+} \mathrm{LT}^{+}$strains of serogroup 0159 , two $\mathrm{CFA} / \mathrm{VI}^{+} \mathrm{LT}^{+}$ strains of serogroup $\mathrm{O} 9,30 \mathrm{PCFO} 66^{+} \mathrm{ST}^{+}$or $\mathrm{ST}^{+} \mathrm{LT}^{+}$strains of serogroups $\mathrm{O} 20, \mathrm{O} 71, \mathrm{O} 98$ and $\mathrm{O} 166$ and $23 \mathrm{CS} 17^{+} \mathrm{LT}^{+}$strains of serogroups 08, O15, O48, O114 and O146. Most of these strains have been reported previously (McConnell et al., 1989a; McConnell et al., 1990).

Ninety-nine ETEC which by ELISA did not produce CFA/I, CS3, CFA/III, CS6, PCFO159:H4, CFA/VI, PCFO166 and CS17 were also screened for type 334 fimbriae. These strains had been tested with CS3 and CS6 antisera but not with CS1, CS2, CS4 and CS5 antisera since all the strains which produced CS1, CS2, CS4 and CS5 apart from a few CS2 strains reported by Smyth (1982) also produced CS3 or CS6. The 99 ETEC consisted of: $78 \mathrm{LT}$-only producing strains of serogroups $\mathrm{O} 7$, O15, O21, O40, O41, O59, O64, O79, O80, O88, O102, O103, O104, O112, O114, O117 and O159; 13 ST-only producing strains of serogroups $\mathrm{O} 2, \mathrm{O} 9, \mathrm{O} 20, \mathrm{O} 30, \mathrm{O} 34, \mathrm{O} 49, \mathrm{O} 64$ and $\mathrm{O} 76$ and eight $\mathrm{ST}^{+} \mathrm{LT}^{+}$strains of serogroups $\mathrm{O} 1, \mathrm{O} 7, \mathrm{O} 15, \mathrm{O} 17, \mathrm{O} 60, \mathrm{O} 109$ and $\mathrm{O} 159$.

Ten ETEC strains were chosen as representatives producing characterized adhesins for Western immunoblot studies in comparison with strain 334. They were H10407, serotype O78:H11 $\mathrm{ST}^{+} \mathrm{LT}^{+} \mathrm{CFA} / \mathrm{I}^{+}$(Evans et al., 1975); E9188, serotype O6:H16, $\mathrm{ST}^{+} \mathrm{LT}^{+} \mathrm{CS}_{1}{ }^{+} \mathrm{CS}_{3}{ }^{+}$; 48333 serotype O6:H16, $\mathrm{ST}^{+} \mathrm{LT}^{+} \mathrm{CS} 2{ }^{+} \mathrm{CS}^{+}$ (Cravioto et al., 1982; McConnell et al., 1989 b); E. coli 31-10, serotype O25: $\mathrm{H}^{-} \mathrm{LT}^{+} \mathrm{CFA} / \mathrm{III}^{+} \mathrm{CS}^{+}$(Honda et al., 1984; McConnell \& Rowe, 1989); E11881, serotype $\mathrm{O} 25: \mathrm{H}_{4} 2, \mathrm{ST}^{+} \mathrm{LT}^{+} \mathrm{CS}^{+}{ }^{+} \mathrm{CS}^{+}$; E17018, serotype $0167: \mathrm{H} 5, \mathrm{ST}^{+} \mathrm{CS}^{+} \mathrm{CS}^{+}$(Thomas et al., 1985; McConnell et al., 1988); E. coli 350C1, serotype O159:H4, $\mathrm{ST}^{+} \mathrm{LT}^{+} \mathrm{PCFO} 159: \mathrm{H}^{+}$ (Tacket et al., 1987); PE360, serotype O9a : $\mathrm{H}^{-}, \mathrm{LT}^{+} \mathrm{PCFO}$ (Heuzenroeder et al., 1990); E7476, serotype O166:H27, ST ${ }^{+} \mathrm{PCFO}_{66}{ }^{+}$ (McConnell et al., 1989a) and E20738 serotype O114:H21, $\mathrm{LT}^{+} \mathrm{CS} 17^{+}$ (McConnell et al., 1990).

Enterotoxin tests. Two systems were used for ST and LT testing: animal or tissue culture methods to detect enterotoxin production and DNA probes to detect genes coding for enterotoxins. ST production was detected by the infant mouse test (Dean et al., 1972) and LT production was detected by the use of Y-1 adrenal cells (Donta et al., 1974). The DNA probes are described in the hybridization section.

MRHA and MSHA. Strains were grown overnight on CFA agar (Cravioto et al., 1982) containing bile salts (McConnell et al., 1989a) and tested for haemagglutination with guinea pig, human and bovine red blood cells in the presence of $0.5 \%$ mannose for adhesion fimbriae, and with guinea pig red blood cells without mannose for type 1 fimbriae as previously described (Cravioto et al., 1982).

Drug resistance and colicin production. Strains were tested for drug resistance (McConnell et al., 1989a) and colicin production by the agar overlay method described by Fredericq (1957).

Isolation of MRHA-positive and -negative colonies. Twenty colonies of strain 334 and an ETEC strain of serogroup O114:H49, E29101, were streaked on slopes of CFA agar containing bile salts and grown overnight at $37^{\circ} \mathrm{C}$. One of the twenty colonies of each strain tested for MRHA with bovine red blood cells was found to be MRHA-negative. These isolates were tested for ST and LT by DNA probe, tissue culture and the infant mouse test as previously described. Because the original 
cultures contained a mixture of MRHA-positive and -negative colonies, single MRHA-positive colonies, designated 334A and E29101A, were also isolated and used in subsequent tests. MRHApositive and -negative colonies of strain E17018 had been isolated previously (Thomas et al., 1985).

Preparation of antisera. Bacterial strain 334A was grown overnight on CFA agar containing bile salts. Peptone water suspensions were made, formalinized and used to immunize rabbits as described previously (Cravioto et al., 1982). The antiserum was absorbed twice with the MRHA-negative derivative strain $334 \mathrm{C}$ (see Table 1 ) at $50^{\circ} \mathrm{C}$ for $2 \mathrm{~h}$ first undiluted and then as a 1 in 10 dilution. Antiserum raised to strain E17018A, and made specific for CS5 by absorption, has been described previously (Thomas et al., 1985).

Preparation of crude fimbriae. Whole cell suspensions of strains were prepared for immunodiffusion and ELISA by growing the strains overnight on CFA agar containing bile salts at $37^{\circ} \mathrm{C}$. For immunodiffusion tests bacteria were scraped from 6 inch plates into $1.5 \mathrm{ml} 0.85 \%$ $\mathrm{NaCl}$ and for ELISAs bacteria were scraped from slants into $2 \mathrm{ml}$ $0.05 \mathrm{M}$-sodium carbonate/bicarbonate buffer ( $\mathrm{pH} \mathrm{9.6)}$. Both types of suspension were then heated at $60^{\circ} \mathrm{C}$ for $30 \mathrm{~min}$. Fimbrial extracts for SDS-PAGE were made as immunodiffusion preparations and then centrifuged (MSE MicroCentaur) for $2 \mathrm{~min}$ at 5000 r.p.m.; the supernatant was stored at $-10^{\circ} \mathrm{C}$.

Immunodiffusion. Ouchterlony gel immunodiffusion was done in $0.75 \%$ agar as described previously (Cravioto et al., 1982).

ELISAs. The crude fimbrial extracts of strains were used to coat wells in a microtitre plate and antigens were detected using specific antisera as described previously (McConnell \& Rowe, 1989).

SDS-PAGE and Western immunoblotting. Fimbrial subunits were separated by SDS-PAGE by the method of Laemmli (1970) using vertical slab gels. Extracts were run on $20 \%(\mathrm{w} / \mathrm{v})$ polyacrylamide gels for $3.5 \mathrm{~h}$ at $50 \mathrm{~mA}$. Proteins of known molecular mass were run on the same gel. Western immunoblotting was done by electroblotting SDSPAGE profiles onto nitrocellulose membranes $(0.35 \mathrm{~A}, 2 \mathrm{~h})$ as described by Towbin et al. (1979). The membranes were incubated with shaking at room temperature for $30 \mathrm{~min}$ in phosphate-buffered saline (PBS: $0.15 \mathrm{M}-\mathrm{NaCl}, 0.15 \mathrm{M}$-sodium phosphate, $\mathrm{pH} 7.2$ ) containing $5 \%$ (w/v) fat-free skimmed milk (blocking buffer). The membrane was heat sealed in a plastic bag and incubated overnight at $4{ }^{\circ} \mathrm{C}$ in blocking buffer containing absorbed antiserum $\left(1 \mu \mathrm{g}\right.$ protein $\mathrm{ml}^{-1}$ loaded on the gel). The membrane was then washed for three 10 min periods in PBS. Bound antibodies were detected by incubating membranes with goat anti-rabbit IgG conjugated to alkaline phosphatase (Sigma) diluted 1 in 2000 with blocking buffer at room temperature for $4 \mathrm{~h}$. After three 10 min washes in PBS the membrane was rinsed for two min in an alkaline phosphatase buffer (Tris/ $\mathrm{HCl}, 100 \mathrm{~mm} ; \mathrm{NaCl}, 100 \mathrm{~mm}$; $\mathrm{MgCl}_{2}, 50 \mathrm{mM}$; $\mathrm{pH} 9.5$ ). It was transferred to $15 \mathrm{ml}$ fresh alkaline phosphatase buffer, to which had been added $69 \mu \mathrm{l}$ nitroblue tetrazolium salt $(75 \mathrm{mg}$ in $70 \%, \mathrm{v} / \mathrm{w}$, dimethylformamide, and $55 \mu \mathrm{l} 5$ bromo-4-chloro-3-indolyl phosphate toluidinium salt $\left(50 \mathrm{mg} \mathrm{ml}^{-1}\right.$ in dimethylformamide) and colouration was allowed to occur in the dark.

Plasmid DNA studies. Plasmid DNA was prepared by the method of Birnboim \& Doly (1979) and separated by electrophoresis on $0.5 \%$ or $0.6 \%$ agarose gels as described previously (Willshaw et al., 1979). Molecular masses of the plasmids were determined relative to standard plasmids run on the same gel.

DNA hybridization. Plasmids encoding production of LT and/or ST were identified with specific probes. These comprised oligonucleotides labelled with alkaline phosphatase and supplied in kit form (SNAP systems; DuPont-NEN). The ST probe contained both STA1- and STA2-specific sequences. Hybridization was done by methods recom- mended by the manufacturer (McConnell et al., 1989a). Plasmid DNA of strains was separated by gel electrophoresis and blotted to nylon membranes (Hybonds N; Amersham) as described previously (McConnell et al., 1988).

Electron microscopy. The strains were grown on CFA agar containing bile salts for two $24 \mathrm{~h}$ periods to give maximum expression of the colonization factor and to suppress the production of type 1 fimbriae. For electron microscopy a thick suspension of each culture was made in peptone water containing $4 \%(\mathrm{v} / \mathrm{v})$ formaldehyde and applied to a grid before staining with $1 \%(\mathrm{w} / \mathrm{v})$ phosphotungstic acid. For immunoelectron microscopy cultures were suspended in peptone water without formaldehyde, applied to a grid and treated with antiserum diluted 1 in 10 in PBS. The grids were stained with $3 \%(w / v)$ phosphotungstic acid grids (McConnell et al., 1981).

\section{Results}

\section{Characterization of strain $334 \mathrm{~A}$ and a variant $334 \mathrm{C}$}

The properties of strain $334 \mathrm{~A}$ are listed in Table 1 and are identical to the properties of the original strain 334 described by Thorne et al. (1979). Strain 334A was MRHA-negative when grown on CFA agar plus bile salts at $22^{\circ} \mathrm{C}$, although it had been positive when grown at $37^{\circ} \mathrm{C}$. An MRHA-negative variant, $334 \mathrm{C}$, from the original culture of strain 334 was isolated and its properties compared to that of the MRHA-positive colony 334A. Variant $334 \mathrm{C}$ was negative for ST and LT production but still possessed LT plasmid genes as determined by LT probe (Table 1). Plasmid studies revealed strains $334 \mathrm{~A}$ and $334 \mathrm{C}$ to have four plasmids but the largest plasmid in 334A was $90 \mathrm{MDa}$ and that in variant $334 \mathrm{C}$ was $78 \mathrm{MDa}$. The other plasmids were the same size in the two strains. Southern blotting showed the $90 \mathrm{MDa}$ plasmid to code for ST and LT in strain 334A and the $78 \mathrm{MDa}$ plasmid to code for LT only in strain 334C. It seemed likely that deletion from the $90 \mathrm{MDa}$ plasmid found in strain 334A resulted in loss of ST, LT and MRHA production to give the $78 \mathrm{MDa}$ plasmid seen in strain 334C. Examination of strains $334 \mathrm{~A}$ and $334 \mathrm{C}$ by electron microscopy showed that 334A produced helical fimbriae of diameter 3.5 to $6.5 \mathrm{~nm}$ (Fig. 1a) similar in morphology to CS5 fimbriae (Manning et al., 1987; Knutton et al., 1989) while the variant $334 \mathrm{C}$ did not produce any helical fimbriae (not shown).

Comparison of the fimbriae of strains $334 \mathrm{~A}$ and E17018A

An antiserum was raised to strain $334 \mathrm{~A}$ and absorbed with variant $334 \mathrm{C}$; this antiserum reacted with the helical, CS5-like fimbriae of strain 334A in immunoelectron microscopy (Fig. 1b). However, the CS5 fimbriae of strain E17018A did not coat with the antistrain 334A absorbed serum (result not shown). In a 

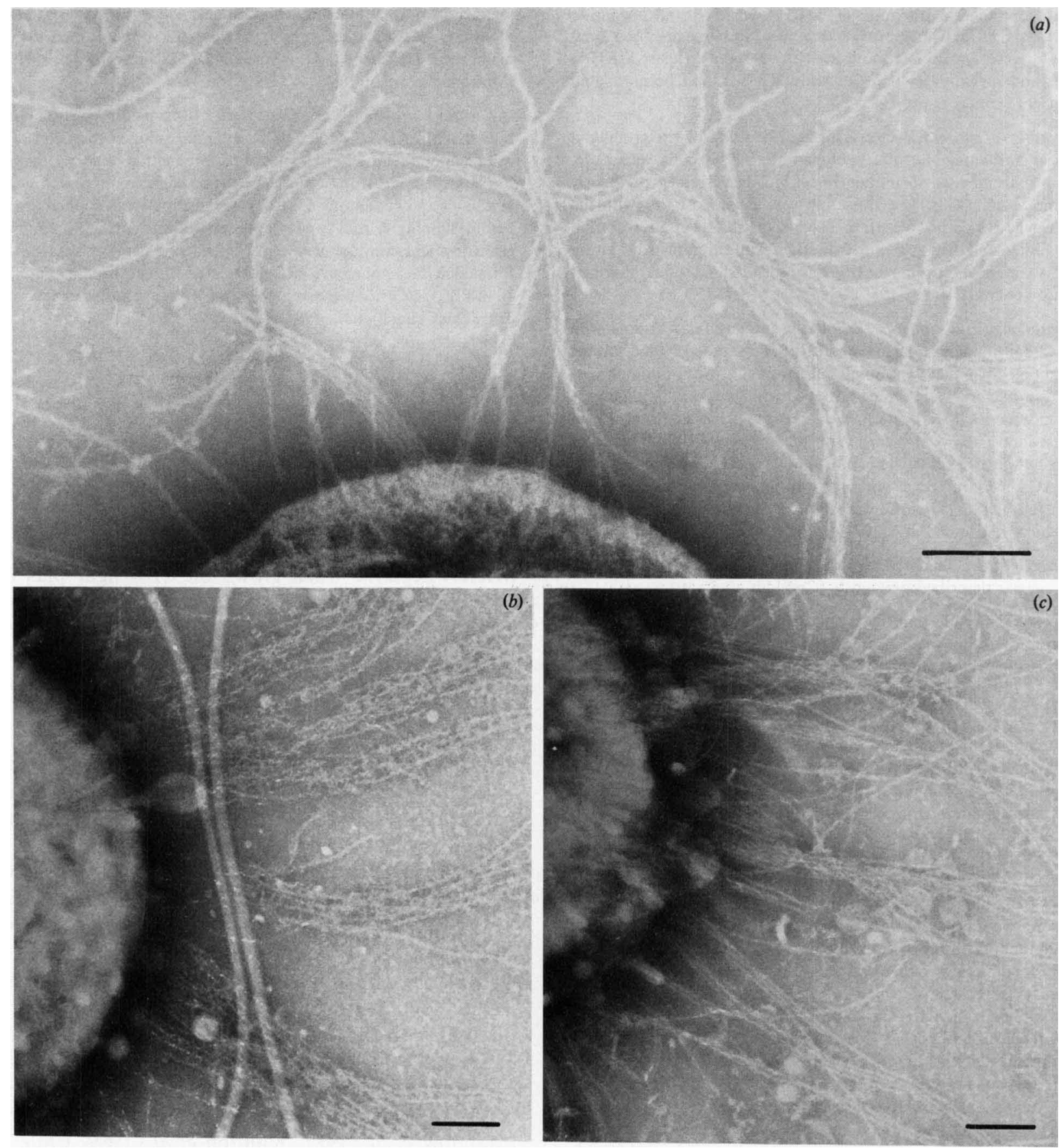

Fig. 1. Negative staining with phosphotungstic acid showing the helical fimbriae of strain 334A. (a) No antiserum added; (b) with addition of anti-strain 334A serum (also shows flagella); (c) with addition of CS5 antiserum raised against strain E17018A. Bars, $100 \mathrm{~nm}$.

similar way fimbriae of strain $334 \mathrm{~A}$ were not coated by CS5 antiserum (Fig. 1c).

The absorbed antiserum prepared to strain 334A did not react with strains producing $\mathrm{CFA} / \mathrm{I}$ or $\mathrm{CS} 1, \mathrm{CS} 2$, CS3, CS4 and CS6 in immunodiffusion tests not did it react with CS5 producing strains. Fig. 2(a) shows the reactions of heated suspensions of strain $334 \mathrm{~A}$, two strains of serogroup O114, E29101A and E23420 which will be described later and three strains of serotype O167:H5, E17018A, E10703 and E13954 which produced CS5 and CS6. Antiserum raised to strain 334A gave an immune precipitate with a heated suspension prepared from strain 334A but not against the three strains producing CS5. Conversely, CS5 antiserum 
(a)

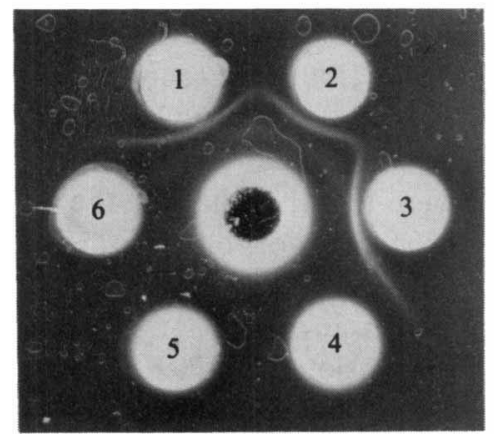

(b)

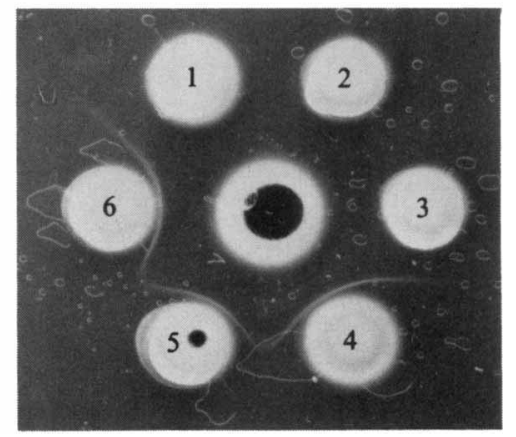

Fig. 2. Immunodiffusion tests with heated whole cell suspensions. Antigen wells contained the following strains: $1,334 \mathrm{~A}(\mathrm{O} 15: \mathrm{H} 11$, MRHA-positive); 2, E29101A (O114:H49, MRHA-positive); 3, E23420 (O114:H-, MRHA-positive); 4, E10703 (O167:H5, CS5-, CS6-positive); 5, E13954 (O167:H5, CS5-, CS6-positive); 6, E17018A (O167:H5, CS5-, CS6-positive). Centre wells: (a) absorbed antistrain 334A serum; (b) CS5 antiserum raised against strain E17018A.

Table 1. Properties of ETEC and their MRHA negative variants

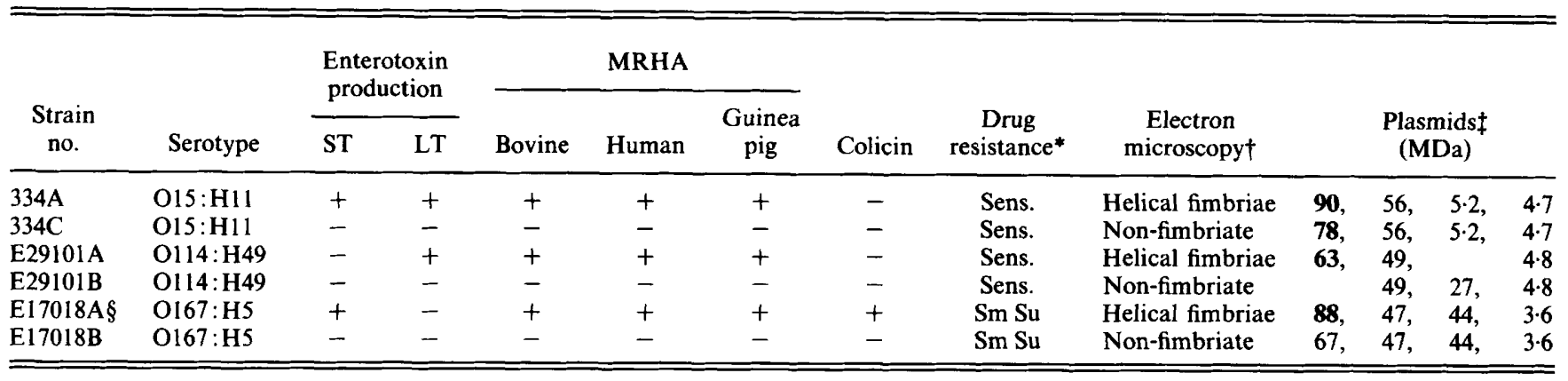

* Sens., sensitive; Sm, streptomycin; Su, sulphonamides.

$\uparrow$ The designation helical fimbriae indicates that these were the predominant fimbrial type. A few rod-like fimbriae were seen sometimes; these were probably type 1 fimbriae. The designation non-fimbriate indicates that $>90 \%$ of the cells lacked fimbriae.

$\ddagger$ Plasmids in bold type were shown to code for enterotoxins by DNA probe tests. The 90 MDa plasmid coded for ST and LT, the 78 and 63 MDa plasmids for LT and the 88 MDa plasmid for ST.

$\S$ This strain produces CS5 and CS6 (Thomas et al., 1985; McConnell et al., 1988).

reacted with strains E17018A, E10703 and E13954 but not with strain 334A (Fig. $2 b$ ).

When a heated suspension of strain 334A was tested by ELISA with absorbed antisera for CFA/I, CS1 to CS6, CFA/III, CFA/VI, PCFO159:H4, PCFO166 and $\mathrm{CS} 17$, the results were all negative except in the test with CS5 antiserum. Here a positive reaction was obtained but this was less than half the value obtained with the control strain E17018A. In a similar way the antiserum raised to strain 334A reacted with strain E17018A but the strength of the reaction was less than half of the value obtained with the control strain 334A. Antisera to strain 334A fimbriae and CS5 fimbriae were serially diluted and tested in ELISAs against heated suspensions of strains 334A, 334C, E17018A and E17018B (Fig. 3). The absorbance value when strain E17018A was tested with anti-strain 334A serum initially fell more rapidly than the value for the parent strain as the antiserum was diluted. Reciprocal results were obtained with strains E17018A and 334A with CS5 antiserum (results not shown).

After SDS-PAGE a strong polypeptide band of a possible fimbrial subunit size of $21.5 \mathrm{kDa}$ was seen in a heated extract from strain 334A (Fig. 4a) but not in an extract from strain $334 \mathrm{C}$ (not shown). This polypeptide was similar in size to the subunit of the CS5 fimbriae of strain E17018A (Fig. 4a). To investigate cross-reactions between fimbrial subunits, Western immunoblots were done using SDS-PAGE extracts prepared from strains 334A and E17018A. The absorbed antisera raised to both strains reacted strongly with the possible fimbrial 


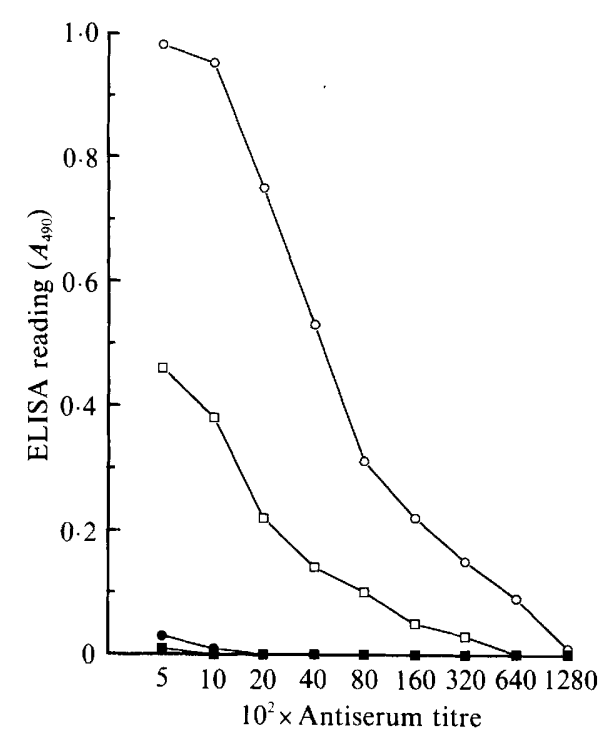

Fig. 3. ELISAs of heated whole cell suspensions of ETEC strains 334A (O15:H1 1, MRHA-positive) (O), 334C (O15:H11, MRHA-negative) (O), E17018A (O167:H5, MRHA-positive) ( $\square$ ) and E17018B (O167:H5, MRHA-negative) ( $\square$ ) using doubling dilutions of absorbed anti-strain 334A serum. (Note that the scale for antiserum titre is logarithmic.) Representative values from one of three experiments are shown.

subunit polypeptides from strain 334A (Fig. $4 b, c$ ). The reaction of $334 \mathrm{~A}$ antiserum with the subunits of E17018A fimbriae varied from very weak to none at all (Fig. $4 b$ ) while with CS5 antiserum the immune reaction was very weak (Fig. $4 c$ ).

\section{Screening of ETEC expressing known colonization factors}

One-hundred and forty-one ETEC with known CFAs as detailed in Methods were tested by ELISA using the absorbed antiserum raised to strain 334A. All 15 strains expressing CS5 as detailed in Methods gave a weak reaction of less than half the value of the reaction with strain 334A, whilst the other strains gave no reaction.

The ten type strains producing known colonization factors described in Methods and strain 334A were tested by Western immunoblot using absorbed antisera raised against strains 334A and E17018A. Both antisera gave positive reactions with the fimbrial subunits from strains 334A and E17018A (as described above though the reaction with CS5 antiserum was very weak) but with none of the others.

\section{Screening of ETEC with undetermined colonization} factors

Ninety-nine ETEC were tested with the absorbed antistrain 334A serum by ELISA. Two $\mathrm{ST}^{+} \mathrm{LT}^{+}$strains of serotype $\mathrm{O} 15: \mathrm{H} 11$, one $\mathrm{LT}^{+}$strain of serotype O103:H49 and $20 \mathrm{LT}^{+}$strains of serotypes $\mathrm{O} 114: \mathrm{H}^{-}$or O114:H49 were found to give positive readings. These 99 ETEC were then tested with antiserum to CS5 and the 23 strains that were positive gave ELISA readings that were less than half of the $334 \mathrm{~A}$ antiserum values. The properties of one absorbed anti-strain 334A serum positive strain, E29101A of serotype O114:H49, are shown in Table 1. In immunodiffusion tests heated suspensions of E29101A reacted with anti-strain 334A serum but not with CS5 antiserum (Fig. 2). Strain E23420 of serotype $\mathrm{O} 114: \mathrm{H}^{-}$reacted in an identical fashion to E29101A (Fig. 2). The properties of the fimbriae of strain E29101A were identical to those of the fimbriae of strain 334A. Plasmid analysis on these strains revealed a profile different to strain 334A. A plasmid of $63 \mathrm{MDa}$ in E29101A coded for LT production. In the LT-negative, MRHA-negative variant E29101B the $63 \mathrm{MDa}$ plasmid was absent but a $27 \mathrm{MDa}$ plasmid was seen. It seemed likely that the $63 \mathrm{MDa}$ plasmid had deleted to $27 \mathrm{MDa}$, leading to loss of LT and MRHA production.

\section{Discussion}

The fimbriae of strain 334 have been shown to attach to buccal cells and erythrocytes (Thorne et al., 1979) and further characterization has confirmed their similarity to other human colonization factors. MRHA-negative, toxin negative derivatives of strains 334 and E29101 were readily isolated. The original cultures of the strains had been kept on Dorset Eggs for 8 and 5 years respectively, so that the high rate of plasmid deletion with resulting loss of MRHA and toxin production was not unexpected. This plasmid instability has been reported previously (McConnell et al., 1988). Because the 334A fimbriae were similar to CS5 fimbriae in morphology, the antigenic relationship of $334 \mathrm{~A}$ and CS5 fimbriae was studied using polyclonal antisera. When the fimbriae were examined by immuno-electron microscopy there was no cross-reaction between CS5 antiserum and $334 \mathrm{~A}$ fimbriae and vice versa but the polypeptides from the fimbriae of strains 334A and E17018A were the same size, about $21.5 \mathrm{kDa}$, and reacted with the antisera raised against strains 334A and E17018A in a similar way. The weaker reaction of the CS5 polypeptide presumably indicates differences in the subunit structure with fewer antigenic sites on these fimbrial subunits. It seemed that the intact fimbriae examined by immunoelectron microscopy were antigenically distinct but when the fimbrial protein was denatured and run on SDSPAGE gels the subunit polypeptides were seen to share common epitopes. The partial reaction in the ELISA 
(a)

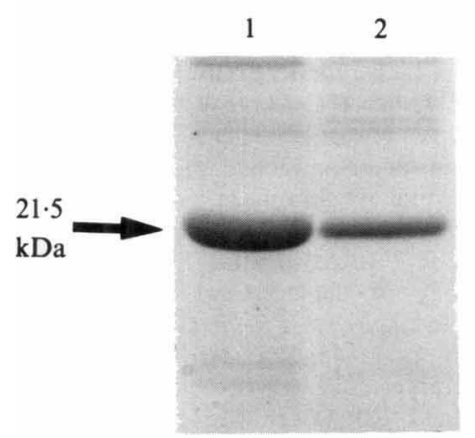

(b)

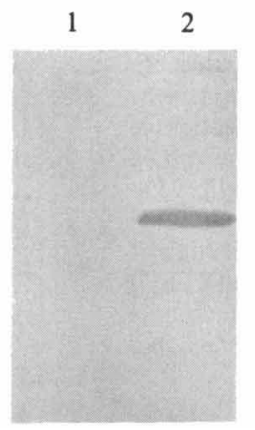

(c)

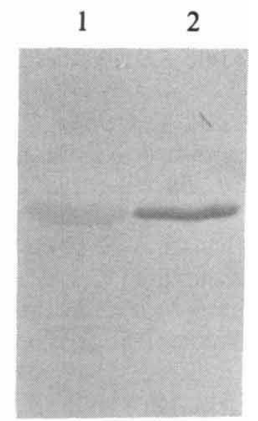

Fig. 4. (a) SDS-PAGE profiles of partially purified fimbrial preparations of strains E17018A (lane 1) and 334A (lane 2). (b,c) Western blots of SDS-PAGE profiles of partially purified fimbrial preparations of strains E17018A (lane 1) and 334A (lane 2) with the addition of $(b)$ anti-strain $334 \mathrm{~A}$ antiserum $(30 \mu \mathrm{l}$ per lane) or $(c)$ CS5 antiserum raised against strain E17018A (30 $\mu \mathrm{l}$ per lane). Arrows indicate the positions and size of the fimbrial polypeptides.

may be due to some denaturing of the fimbriae by the heat treatment. A similar relationship has been observed between the fimbrial antigens CS31A and K88 (Girardeau et al., 1988) and CFA/I and CS4 (McConnell et al., 1989 b). Deneke et al. (1981) did not give a specific name to the fimbriae of strain 334, describing them as belonging to serotype 1 . Since the intact fimbriae of strain 334A have now been shown to be antigenically distinct from the other known colonization factors including CS5 we propose to give them a separate designation, namely CS7.

CS7 was demonstrated on $\mathrm{ST}^{+} \mathrm{LT}^{+}$strains of serotype O15:H11 and $\mathrm{LT}^{+}$only strains of serotypes O103:H49, O114:H49 and O114: $\mathrm{H}^{-}$. Those ETEC came mainly from South-East Asia, but one strain was isolated in Peru, areas where CS5 producing strains are also found (Thomas et al., 1985; M. M. McConnell \& M. Hibberd, unpublished). The antigenic relationship between CS5 and CS7 may be sufficient for strains carrying one type of $\mathrm{CS}$ to give protection against strains producing the other type and this possibility is being tested in an animal model.

CS7 is produced by $E$. coli which also produce ST and $\mathrm{LT}$ or $\mathrm{LT}$ only. ST ${ }^{+} \mathrm{LT}^{+}$strains have been shown to be significant in ETEC disease but it has been postulated that strains which produce LT only are not important as pathogens because they are found in ETEC of a wide variety of serotypes and may be as common in controls as diarrhoeal cases (Reis et al., 1980; Cravioto et al., 1988). LT only producing strains have been shown to be pathogenic in volunteers although the diarrhoea was less severe than that caused by $\mathrm{ST}^{+} \mathrm{LT}^{+}$strains (Levine et al., 1979). The pathogenicity of $\mathrm{LT}^{+}$strains possessing the putative colonization factor CS7 needs to be assessed further.
This work was supported by a grant from the Diarrhoeal Diseases Control Program of the World Health Organization.

\section{References}

Birnboim, H. C. \& Doly, J. (1979). A rapid alkaline extraction procedure for screening recombinant plasmid DNA. Nucleic Acids Research 7, 1513-1523.

Cravioto, A., Scotland, S. M. \& Rowe, B. (1982). Hemagglutination activity and colonization factor antigens I and II in enterotoxigenic and non-enterotoxigenic strains of Escherichia coli isolated from humans. Infection and Immunity 36, 189-197.

Cravioto, A., Reyes, R. E., Ortega, R., Fernandez, G., HernanDEZ, R. \& LOPEZ, D. (1988). Prospective study of diarrhoeal disease in a cohort of rural Mexican children: incidence and isolated pathogens during the first two years of life. Epidemiology and Infection 101, 123-134.

Darfeuille-Michaud, A., Forestier, C., Joly, B. \& Cluzel, R. (1986). Identification of a nonfimbrial adhesive factor of an enterotoxigenic Escherichia coli strain. Infection and Immunity 52, 468-475.

Dean, A. G., Ching, Y.-C., Williams, R. G. \& Harden, L. B. (1972). Test for Escherichia coli enterotoxin using infant mice : application in a study of diarrhea in children in Honolulu. Journal of Infectious Diseases 125, 407-411.

Deneke, C. F., Thorne, G. M. \& Gorbach, S. L. (1981). Serotypes of attachment pili of enterotoxigenic Escherichia coli isolated from humans. Infection and Immunity 32, 1254-1260.

Donta, S. T., Moon, H. W. \& WhIPP, S. C. (1974). Detection of heatlabile Escherichia coli enterotoxin with the use of adrenal cells in tissue culture. Science 183, 334-336.

Evans, D. G. \& Evans, D. J., JR (1978). New surface-associated heatlabile colonization factor antigen (CFA/II) produced by enterotoxigenic Escherichia coli of serogroups $\mathrm{O} 6$ and $\mathrm{O} 8$. Infection and Immunity 21, 638-647.

Evans, D. G., Silver, R. P., Evans, D. J., Chase, D. G. \& Gorbach, S. L. (1975). Plasmid-controlled colonization factor associated with virulence in Escherichia coli enterotoxigenic for humans. Infection and Immunity 12, 656-667.

FrEDERICQ, P. (1957). Colicins. Annual Review of Microbiology 11, 722.

Girardeau, J. P., Vartanian, M. D., Oller, J. L. \& Contrepois, M. (1988). CS31A, a new K88-related fimbrial antigen on bovine enterotoxigenic and septicemic Escherichia coli strains. Infection and Immunity 56, 2180-2188. 
Heuzenroeder, M. W., Elliot, T. R., Thomas, C. J., Halter, R. \& MANNING, P. A. (1990). A new fimbrial type (PCFO9) on enterotoxigenic Escherichia coli $\mathrm{O} 9: \mathrm{H}^{-} \mathrm{LT}^{+}$isolated from a case of infant diarrhea in Central Australia. FEMS Microbiology Letters 66, $55-60$.

Honda, T., Arita, M. \& Miwatani, T. (1984). Characterization of new hydrophobic pili of human enterotoxigenic Escherichia coli: a possible new colonization factor. Infection and Immunity 43, 959965.

KnUtTon, S., LloYd, D. R. \& MCNEISH, A. S. (1987). Identification of a new fimbrial structure in enterotoxigenic Escherichia coli (ETEC) serotype $\mathrm{O} 148: \mathrm{H} 28$ which adheres to human intestinal mucosa: a potentially new human ETEC colonization factor. Infection and Immunity 55, 86-92.

Knutton, S., MCConnell, M. M., Rowe, B. \& MCNeish, A. S. (1989). Adhesion and ultrastructural properties of human enterotoxigenic Escherichia coli producing CFA/III and CFA/IV. Infection and Immunity 57, 3364-3371.

LAEMMLI, U. K. (1970). Cleavage of structural proteins during the assembly of the head of bacteriophage T4. Nature, London 227, 680685 .

Levine, M. M., Nalin, D. R., Hoover, D. L., Bergquist, E. J., HoRNICK, R. B. \& Young, C. R. (1979). Immunity to enterotoxigenic Escherichia coli. Infection and Immunity 23, 729-736.

McConnell, M. M. \& Rowe, B. (1989). Prevalence of the putative colonization factors CFA/HI and PCFOl 59:H4 in enterotoxigenic Escherichia coli. Journal of Infectious Diseases 159, 582-586.

McConnell, M. M., Smith, H. R., Willshaw, G. A., Field, A. M. \& RowE, B. (1981). Plasmids coding for colonization factor antigen I and heat-stable enterotoxin production isolated from enterotoxigenic Escherichia coli: comparison of their properties. Infection and Immunity 32, 927-936.

McConnell, M. M., Thomas, L. V., Scotland, S. M. \& Rowe, B. (1986). The possession of coli surface antigen CS6 by enterotoxigenic Escherichia coli of serogroups $\mathrm{O} 25, \mathrm{O} 27, \mathrm{O} 148$ and 0159 : a possible colonization factor? Current Microbiology 14, 51-54.

McConnell, M. M., Thomas, L. V., Willshaw, G. A., Smith, H. R. \& RowE, B. (1988). Genetic control and properties of coli surface antigens of colonization factor antigen IV (PCF8775) of enterotoxigenic Escherichia coli. Infection and Immunity 56, 1974-1980.

McConnell, M. M., Chart, H., Field, A. M., Hibberd, M. \& Rowe, B. $(1989 a)$. Characterization of a putative colonization factor (PCFO166) of enterotoxigenic Escherichia coli of serogroup 0166. Journal of General Microbiology 135, 1135-1144.

McConnell, M. M., Chart, H. \& Rowe, B. (1989b). Antigenic homology within human enterotoxigenic Escherichia coli fimbrial colonization factor antigens: CFA/I, coli-surface-associated antigens (CS)1, CS2, CS4 and CS17. FEMS Microbiology Letters 61, 105108.
McConnell, M. M., Hibberd, M., Field, A. M., Chart, H. \& Rowe, B. (1990). Characterization of a new putative colonization factor (CS17) from a human enterotoxigenic Escherichia coli of serotype $\mathrm{O} 114: \mathrm{H} 21$ which produces only heat-labile enterotoxin. Journal of Infectious Diseases 161, 343-347.

Manning, P. A., Higgins, G. D., Lumb, R. \& Lanser, J. A. (1987). Colonization factor antigens and a new fimbrial type, CFA/V, on O115: $\mathrm{H} 40$ and $\mathrm{H}^{-}$strains of enterotoxigenic Escherichia coli in Central Australia. Journal of Infectious Diseases 156, 841-844.

Merson, M. H., Black, R. E., Khan, M. U. \& HuQ, I. (1980). Epidemiology of cholera and enterotoxigenic Escherichia coli diarrhoea. In Cholera and Related Diseases, 43rd Nobel Symposium, Stockholm, pp. 34-45. Edited by O. Ouchterlony \& J. Holmgren. Basel: S. Karger.

PARRY, S. H., \& RoOKe, D. M. (1985). Adhesins and colonization factors of Escherichia coli. In The Virulence of Escherichia coli, Society for General Microbiology Special Publication no. 13, pp. 79-155. Edited by M. Sussman. London: Academic Press.

Reis, M. L. H., Matos, D. P., Pestana de Castro, A. F., Toledo, R. F. \& TRABULSI, R. L. (1980). Relationship among enterotoxigenic phenotypes, serotypes and sources of strains in enterotoxigenic Escherichia coli. Infection and Immunity 28, 24-27.

SACK, R. B. (1975). Human diarrheal disease caused by enterotoxigenic Escherichia coli. Annual Review of Microbiology 29, 333-353.

SMYTH, C. J. (1982). Two mannose-resistant haemagglutinins on enterotoxigenic Escherichia coli of serotype $06: \mathrm{K} 15: \mathrm{H} 16$ or $\mathrm{H}^{-}$ isolated from travellers' and infantile diarrhoea. Journal of General Microbiology 128, 2081-2096.

TaCket, C. O., ManeVal, D. R. \& Levine, M. M. (1987). Purification, morphology, and genetics of a new fimbrial putative colonization factor of enterotoxigenic Escherichia coli O159:H4. Infection and Immunity 55, 1063-1069.

ThомAs, L. V. (1985). An investigation of the adhesive properties of enterotoxigenic Escherichia coli isolated from humans. $\mathrm{PhD}$ thesis, CNAA, UK.

Thomas, L. V., McConnell, M. M., Rowe, B. \& Field, A. M. (1985). The possession of three novel coli surface antigens by enterotoxigenic Escherichia coli strains positive for the putative colonization factor PCF8775. Journal of General Microbiology 131, 2319-2326.

Thorne, G. M., Deneke, C. F. \& Gorbach, S. L. (1979). Haemagglutination and adhesiveness of toxigenic Escherichia coli isolated from humans. Infection and Immunity 23, 690-699.

Towbin, H., Staehelin, T. \& Gordon, J. (1979). Electrophoretic transfer of proteins from polyacrylamide gels to nitrocellulose sheets: procedure and some applications. Proceedings of the National Academy of Sciences of the United States of America 76, 4350-4354.

Willshaw, G. A., Smith, H. R.. \& Anderson, E. S. (1979). Application of agarose gel electrophoresis to the characterization of plasmid DNA in drug-resistant enterobacteria. Journal of General Microbiology 114, 15-25. 